\title{
Apmokamų vaiko priežiūros atostogų politikos vertinimas Lietuvoje
}

\author{
Rūta Brazienè \\ Vilniaus universitetas, \\ Universiteto g. 9/1, LT-01131 Vilnius \\ Sonata Vyšniauskienè \\ Lietuvos socialiniu tyrimu centras \\ A.Goštauto g. 9, LT-01108 Vilnius \\ cross $^{r e f}$ http://dx.doi.org/10.5755/j01.ppaa.18.3.24706
}

\begin{abstract}
Anotacija. Straipsnyje yra analizuojama apmokamu vaiko priežiūros atostogu politika, aptariamas teisinis reglamentavimas, paramos šeimai sistema Lietuvoje ir bei pateikiamas apmokamu vaiko priežiūros atostogu sistemos vertinimas. Apžvelgiama naujausia ir aktualiausia moksline literatūra palankios šeimos politikos ir apmokamu vaiko priežiūros atostogu srityje. Remiantis Lietuvos statistikos departamento bei socialinio fondo valdybos (SODRA), darbo jegos tyrimo duomenimis (Eurostat LFS), atskleidžiamos tèvu, turinčiu vaikus dalyvavimo darbo rinkoje tendencijos bei motinu ir tèvu apmokamu vaiko priežiūros atostogu pasirinkimai ir vertinimas. Atlikto tyrimo rezultatai atskleide, kad Lietuvoje egzistuojanti apmokamu vaiko priežiūros atostogu sistema iš esmès orientuota tik $\dot{i}$ prarastu pajamu kompensavima tévams, bet nesudaro lygiu galimybiu tolygiam abieju tèvu i sitraukimui $i$ vaiku priežiūra bei dalyvavima darbo rinkoje. Tai patvirtina ir statistiniai duomenys, kad du kartus daugiau moteru nei vyru naudojasi apmokamomis vaiko priežiūros atostogomis, o moteru, turinčiu mažamečiu vaiku dalyvavimo darbo rinkoje rodikliai ženkliai mažèja. Motinu ir tèvu apsisprendima išeiti vaiko priežiūros atostogu pirmiausiai nulemia finansiniai motyvai, sąlygoti mažesnių išmoku dydžiu motinoms.
\end{abstract}

Raktažodžiai: apmokamos vaiko priežiūros atostogos, apmokamu vaiko priežiūros atostogu sistemos vertinimas, palanki šeimai politika

Keywords: paid leave policies, evaluation of paid leave policies system, family friendly policy

\section{İvadas}

Socialinių ekonominių transformacijų, globalizacijos ir narystès ES kontekste Lietuvoje, kaip ir kitose pokomunistinėse šalyse, įvyko daug pokyčių socialinès gerovės ir socialinės apsaugos sistemoje. Europos Sajungos lygmeniu yra akivaizdus poreikis tarpusavyje harmonizuoti socialinès apsaugos sistemas ir sukurti įtraukias gerovès valstybes (Mabala, 2019; Esping-Andersen, 1999; Esping-Andersen, 1996; Esping-Andersen, 1990 ir kt.). Vienas iš apmokamų vaiko priežiūros atostogų tikslų, skatinti lyčių lygybę bei moterų užimtumą darbo rinkoje. Europos Sajungos lygmeniu moterų dalyvavimo darbo rinkoje skatinimas yra vienas iš Strategijos Europa 2020 tikslų, t.y. pasiekti, kad $75 \%$ moterų nuo 20 iki 64 metų dalyvautų darbo rinkoje. Ir nors pastaraisiais dešimtmečiais moteru užimtumas Europoje bei Lietuvoje labai išaugo, galime diskutuoti apie tai ar moteru potencialas yra pilnai panaudojamas darbo rinkoje? Tradicinio pasidalijimo darbu tarp lyčiu modifikacija skatinama per taip vadinamą profesinių ir šeiminių vaidmenų derinimo politiką, kuri apima: apmokamas vaiko priežiūros atostogas, ikimokyklinio ugdymo prieinamumą, šeimai palankias darbo organizavimo formas ir mechanizmus, skatinančius tolygų neapmokamo darbo pasidalijimą tarp vyrų ir moterų.

Palanki šeimai politika viena iš pagrindinių priemonių užtikrinančių tėvų galimybes suderinti vaiko priežiūrą ir dalyvavimą darbo rinkoje. Nepaisant, kad pastaraji dešimtmetį šia tema pakankamai daug diskutuoja tiek mokslininkai, tiek socialinès politikos specialistai, sklandus vaiko priežiūros ir profesinès veiklos suderinimas vis tik išlieka pakankamai aktualia moksline ir praktine problema. 
Paminètina, kad priklausomai nuo palankios šeimai politikos priemonių (apmokamų vaiko priežiūros atostogų, ikimokyklinio ugdymo prieinamumo ir kt.) šie klausimai gana skirtingai sprendžiami ịvairiose šalyse. Tą pirmiausiai atskleidžia apmokamų vaiko priežiūros atostogų sistemų analizė, kuomet matome gana didelę įvairovę tarp skirtingų šeimos ir darbo rinkos politikos priemonių bei tai kokiu mastu skirtingose šalyse yra skatinamas tolygus darbo/profesinès veiklos ir vaikų priežiūros pasidalinimas tarp tėvų. Daugelyje, ypatingai Europos šalių, palankiomis šeimos politikos priemonėmis siekiama užtikrinti lyčių lygybę darbo rinkoje ir kuo labiau įtraukti vyrus ị vaikų priežiūrą (Almqvist, Duvander, 2014; Ferrarini, Duvander, 2009).

Socialinès ir ekonominès transformacijos bei ES integracijos procesai (lyčių lygybès klausimai) bei Lietuvos narystė Europos Sajungoje buvo vienas esminių pokyčių, paskatinusių mokslinę diskusiją apie lyčių lygybę, palankią šeimai politiką, apmokamas vaiko priežiūros atostogas, profesinių ir šeiminių vaidmenų derinimą ir kt. bei atitinkamai mokslinius ir taikomuosius tyrimus šioje srityje. Lyčių lygybès siekiai suformuluoti teisiniuose ir strateginiuose dokumentuose, deja retai virsta realiomis priemonėmis, sudarančiomis palankias galimybes derinti apmokamą darbą ir vaikų priežiūrą. Tą faktą dar kartą patvirtina 2019 m. spalio mèn. Europos lyčių lygybès instituto (EIGE) paskelbtas lyčių lygybès indeksas, kuris rodo, kad Lietuva tarp visų Europos Sajungos šalių yra vienintelè šalis be jokio progreso lyčių lygybės srityje. Vienas rodiklių pagal kurị Lietuva ịvertinta nepalankiausiai yra atotrūkis tarp moterų ir vyrų skiriamo laiko vaikų priežiūrai, kuris $2017 \mathrm{~m}$. siekè net $26 \%$ Be to, nuo 2005 metų Lietuvos lyčių lygybės indeksas (EIGE, 2019) sumažèjo nuo 55.8 iki 55.3 punkto.

Moksliniame diskurse palankios šeimai politikos klausimais galime išskirti keletą pagrindinių krypčių: apmokamų vaiko priežiūros atostogų reglamentavimas (Brazienè, 2019; Brazienė, 2018; Brazienè, 2017; Duvander, Ellingsæter, 2016; Valarino, Duvander et al, 2015, Ferrarini, Duvander, 2009), ikimokyklinio ugdymo prieinamumas (Brazienė, Daukantienė, 2010), palankios šeimos politikos priemonès (Vyšniauskienè, Brazienė, 2017; Stankūnienė ir kt. 2001; Jančaitytė, 2006), profesinių ir šeiminių vaidmenų derinimas (O’Brien, 2017; Reingardienė, Tereškinas, 2006; Hoyman, Duer, 2004).

Šio tyrimo tikslas - pateikti apmokamų vaiko priežiūros atostogų politikos vertinimą Lietuvoje. Tikslui pasiekti iškelti šie uždaviniai: 1) išanalizuoti apmokamų vaiko priežiūros atostogų pagrindines charakteristikas bei teisinį reglamentavimą; 2) išanalizuoti apmokamų vaiko priežiūros atostogų gavèjų struktūrą ir pasirinkimus 2011-2018 m.; 3) pateikti rekomendacijas kaip tobulinti apmokamų vaiko priežiūros atostogų politiką Lietuvoje. Taikyti tyrimo metodai: mokslinès literatūros, strateginių ir teisinių dokumentų bei antrinè statistinių duomenų analizė.

\section{Apmokamos vaiko priežiūros atostogos: samprata ir teisinis reglamentavimas}

Mokslinėje literatūroje pagrindinėmis palankios šeimai politikos priemonėmis yra laikomos apmokamos vaiko priežiūros atostogos (teisè ị apmokamas vaiko priežiūros atostogas, apmokamų vaiko priežiūros atostogų trukmė ir išmokos, vaiko priežiūros atostogų pasirinkimo galimybès, ikimokyklinio ugdymo prieinamumas ir kokybè, šeimai palanki darbo organizacija (pvz. galimybė dirbti ne visu etatu, lankstaus darbo grafiko galimybè ir kt.) (Bučaitė-Vilkė, Purvaneckienè ir kt., 2012; Stankūnienè, 2001 ir kt.; Stankūnienè, 2005 ir kt.). Šios priemonès laikomos sprendžiančiomis darbo ir šeimos gyvenimo suderinimo klausimus, skatinančios gimstamumą ir lyčių lygybę. Paminètina ir finansinių paramos šeimai priemonių sistema, t.y. vaiko pinigai, ivvairios pašalpos, mokesčių lengvatos, (iš dalies) nemokamos viešojo transporto paslaugos, ịvairios būsto subsidijos ir kompensacijos ir kt. Taigi, apibendrintai galime išskirti šias pagrindines palankios šeimai politikos priemones:

1. apmokamų vaiko priežiūros atostogų sistema (apmokamos motinystès/tèvystès atostogos, apmokamos vaiko priežiūros atostogos, atostogos dèl šeimyninių priežasčių, įsivaikinimo atostogos ir kt.);

2. valstybinès vs. privačios vaiko priežiūros paslaugos (vaikų lopšeliai-darželiai, daugiafunkciniai centrai, vaikų priežiūros centrai darbovietėse ir kt.); 
3. vaiko pinigai ir kitos išmokos šeimai ir vaikams;

4. lanksčios užimtumo formos (darbas ne visą darbo dieną, lankstus darbo grafikas, darbas namuose, darbo pasidalijimas su kitu darbuotoju ir kt.).

Apžvelgus apmokamų vaikų priežiūros sistemas Europos Sajungos šalyse, pastebime didžiulę ịvairovę kaip šalys reguliuoja šios politikos klausimus. Paminètina tai, kad ženkliai skiriasi apmokamų vaiko priežiūros atostogų teisinis reglamentavimas, o tuo pačiu teisė ị atostogas, bei jų trukmè ir t.t. Apmokamos vaiko priežiūros atostogos ne tik skiriasi savo trukme, reglamentavimu, dẻl nedarbingumo prarastų pajamų kompensavimo lygiu ir pan., bet ir kitais apsektais. Tačiau pagrindinè idèja daugelyje šalių yra ta pati, t.y. siekis tėvams auginančius mažamečius vaikus išsaugoti darbo vietą ir užtikrinti pajamas. Be to, tarp šalių egzistuoja gana ženklūs skirtumai ir tarp to, kokių tikslų siekiama palankios šeimai politikos priemonemis: skatinti moterų-motinų dalyvavimą darbo rinkoje, aktyvesnị vyrų ịsitraukimą i vaiko priežiūrą, lyčių lygybę, gimstamumą, apsaugoti něščiujų ir pagimdžiusių moterų sveikatą bei sudaryti palankesnes sąlygas derinti profesinius ir šeiminius vaidmenis. Ilgiausias vaiko priežiūros atostogas tèvams suteikia nemaža dalis pokomunistinių šalių (Čekija, Estija, Latvija, Lietuva, Slovakija, Vengrija). Kai kuriose pietų Europos šalyse (Graikijoje, Maltoje) ženklūs skirtumai egzistuoja tarp tėvų dirbančių valstybiniame ir privačiame sektoriuose. Tačiau dažniausiai ne visa vaiko priežiūros atostogų trukmė yra apmokama (detaliau žr. 1 lentelèje).

1 lentelè. Apmokamų vaiko priežiūros atostogų trukmė ES šalyse.

\begin{tabular}{|c|c|c|c|c|c|c|}
\hline \multirow[t]{2}{*}{ ES šalys } & \multicolumn{2}{|c|}{$\begin{array}{c}\text { Motinystès atostogụ } \\
\text { trukmè } \\
\text { (savaitèmis) }\end{array}$} & \multicolumn{2}{|c|}{$\begin{array}{c}\text { Tèvystès atostogụ trukmè } \\
\text { (savaitėmis) }\end{array}$} & \multicolumn{2}{|c|}{$\begin{array}{c}\text { Vaiko priežiūros atostogụ } \\
\text { trukmė } \\
\text { (mènesiais) }\end{array}$} \\
\hline & Iš viso & Apmokamų & Iš viso & Apmokamų & Iš viso & Apmokamų \\
\hline Airija & 39 & 24 & 2 & 2 & 8,4 & $*$ \\
\hline Austrija & 13 & 13 & $\begin{array}{c}\text { Viešasis } \\
\text { sektorius: } 4 \\
\text { Privatus } \\
\text { sektorius: * } \\
\end{array}$ & $*$ & 24 & 14 \\
\hline Belgija & 15 & 15 & 2 & 2 & 8 & 8 \\
\hline Bulgarija & 48 & 48 & 2.1 & 2.1 & 12 & 12 \\
\hline Čekija & 21 & 21 & 1 & 1 & 36 & Nuo 6 iki 48 \\
\hline Danija & 15 & 15 & 2 & 2 & 11.1 & Nuo 7.4 iki 14.7 \\
\hline Estija & 19 & 19 & 2 & 2 & 36 & 36 \\
\hline Graikija & $\begin{array}{c}\text { Viešasis } \\
\text { sektorius } 12 \\
\text { Privatus } \\
\text { sektorius: } 33\end{array}$ & $\begin{array}{c}\text { Viešasis } \\
\text { sektorius } 12 \\
\text { Privatus } \\
\text { sektorius: } 33\end{array}$ & $\begin{array}{c}\text { Viešasis } \\
\text { sektorius } 2 \\
\text { dienos } \\
\text { Privatus } \\
\text { sektorius: } 2 \\
\text { dienos }\end{array}$ & $\begin{array}{l}\text { Viešasis } \\
\text { sektorius } 2 \\
\text { dienos } \\
\text { Privatus } \\
\text { sektorius: } 2 \\
\text { dienos }\end{array}$ & $\begin{array}{c}\text { Viešasis } \\
\text { sektorius } 8 \\
\text { Privatus } \\
\text { sektorius: } \\
120 \text { (5 metai } \\
\text { kiekvienam } \\
\text { iš tèvų) }\end{array}$ & $*$ \\
\hline Ispanija & 19 & 19 & 4 & 4 & 36 & $*$ \\
\hline Italija & 19 & 19 & 4 dienos & 4 dienos & 11 & 11 \\
\hline $\begin{array}{l}\text { Jungtinè } \\
\text { Karalystė }\end{array}$ & 48 & 36 & 1 arba 2 & 1 arba 2 & 4.2 & $*$ \\
\hline Kroatija & 24 & 24 & $*$ & $*$ & 8 & Nuo 8 iki 16 \\
\hline Latvija & 13 & 13 & 1.3 & 1.3 & 36 & 18 \\
\hline Lenkija & 22 & 22 & 2 & 2 & 7.4 & 7.4 \\
\hline Lietuva & 13 & 13 & 4 & 4 & 36 & 24 \\
\hline Liuksemburgas & 15 & 15 & $*$ & $*$ & 12 & 12 \\
\hline Malta & 18 & 18 & $\begin{array}{c}\text { Viešasis } \\
\text { sektorius: } 1 \\
\text { diena } \\
\text { Privatus } \\
\text { sektorius: } 5 \\
\text { dienos } \\
\end{array}$ & $\begin{array}{c}\text { Viešasis } \\
\text { sektorius: } 1 \\
\text { diena } \\
\text { Privatus } \\
\text { sektorius: } 5 \\
\text { dienos } \\
\end{array}$ & $\begin{array}{c}8 \\
\text { Privatus } \\
\text { sektorius: } 12\end{array}$ & $*$ \\
\hline Nyderlandai & 16 & 16 & 2 dienos & 2 dienos & 12 & $*$ \\
\hline Portugalija & $* * *$ & $* * *$ & $*$ & $*$ & 13 & 13 \\
\hline
\end{tabular}




\begin{tabular}{|c|c|c|c|c|c|c|}
\hline \multirow[t]{2}{*}{ ES šalys } & \multicolumn{2}{|c|}{$\begin{array}{c}\text { Motinystès atostogu } \\
\text { trukmé } \\
\text { (savaitėmis) }\end{array}$} & \multicolumn{2}{|c|}{$\begin{array}{l}\text { Tèvystès atostogų trukmė } \\
\text { (savaitėmis) }\end{array}$} & \multicolumn{2}{|c|}{$\begin{array}{c}\text { Vaiko priežiūros atostogụ } \\
\text { trukmė } \\
\text { (mènesiais) }\end{array}$} \\
\hline & Iš viso & Apmokamų & Iš viso & Apmokamų & Iš viso & Apmokamų \\
\hline Prancūzija & 15 & 15 & 2.2 & 2.2 & 36 & 36 \\
\hline Rumunija & 18 savaičių & 18 & $\begin{array}{c}\text { Nuo } 5 \text { iki } 15 \\
\text { dienų }\end{array}$ & $\begin{array}{c}\text { Nuo } 5 \text { iki } 15 \\
\text { dienų }\end{array}$ & $\begin{array}{c}\text { Nuo } 12 \text { iki } \\
24\end{array}$ & Nuo 12 iki 24 \\
\hline Slovėnija & 14 savaičių & 14 & 4 & 4 & 8.6 & 8.6 \\
\hline Slovakija & $\begin{array}{c}\text { Nuo } 24 \text { iki } \\
29\end{array}$ & $\begin{array}{c}\text { Nuo } 24 \text { iki } \\
29\end{array}$ & $*$ & $*$ & 36 & 36 \\
\hline Suomija & 17 & 17 & 9 & 9 & 6.1 & 6.1 \\
\hline Švedija & $* * *$ & $* * *$ & 1.3 & 1.3 & 18 & 15.9 \\
\hline Vengrija & 26 & 26 & 1 & 1 & 36 & 36 \\
\hline Vokietija & 13 & 13 & $*$ & $*$ & 72 & 28 \\
\hline
\end{tabular}

*** Tik vaiko priežiūros atostogu reglamentavimas

* Nera istatymuose numatytos teisés

Šaltinis:_https://www.leavenetwork.org/fileadmin/user_upload/k_leavenetwork/annual_reviews/Leave_Review_2018.pdf

Motinystès apsauga ir vaiko priežiūros atostogos - tai seniausias su šeima siejamos socialinès gerovès politikos priemonès bei pagrindiniai šeimos politikos elementais visoje Europoje (Neyer, 2003). Siemet kaip tik sukanka 100 metų, kai oficialiai buvo įteisintos motinystès atostogos. Atostogų, skirtų vaiko gimdymui ir priežiūrai, kategorijai priskiriamos motinystès atostogos, tèvystès atostogos ir vaiko priežiūros atostogos. Vaiko priežiūros atostogos (motinystės/tèvystès atostogos, atostogos dèl šeimyninių priežasčių, i̦sivaikinimo atostogos ir kt.) - tai viena pagrindinių priemonių derinant šeimos ir darbo įsipareigojimus. Vaiko priežiūros atostogoms apibūdinti Lietuvoje nėra vieningai priimto termino, tokio, kuris yra plačiai naudojamas anglo saksų šalyse (anglų k. leave policies). Pagal Castles, atostogos vaiko gimdymui ir priežiūrai yra aktyvios politikos priemonès, orientuotos ị moterų užimtumo skatinimą, dviejų darbo užmokesčių šeimų rėmimą, lyčių lygybės užtikrinimą (Castles, 2003).

\section{Apmokamų vaiko priežiūros atostogų sistema Lietuvoje}

Žvelgiant iš istorinès perspektyvos, Lietuvoje apmokamos vaiko priežiūros atostogos $1982 \mathrm{~m}$. pasiekė vienerius metus, o $1989 \mathrm{~m}$. jau buvo suteikiamos iki kol vaikui sukaks treji metai. Paminètina, tai, kad sovietmečiu apmokamos vaiko priežiūros atostogos buvo prieinamos tik motinoms. Lietuvoje esminiai pokyčiai apmokamų vaiko priežiūros atostogų srityje įvyko prieš 2004 m. tampant Europos Sajungos nare, kuomet vyko Lietuvos socialinès politikos harmonizacija su ES. Analizuojant naujausius pastarojo dešimtmečio pokyčius paminètina tai, kad ženklesni pokyčiai įvyko po 2010 metų, kuomet vaiko priežiūros išmokos buvo keletą kartų sumažintos bei įvestos vaiko priežiūros išmokų lubos. Palyginimui galima paminèti tai, kad $2008 \mathrm{~m}$. tèvai turèjo teisę ì 24 mèn. apmokamų atostogų, kurios buvo kompensuojamos $100 \%$ buvusio atlyginimo. Dèl krizès poveikio, $2009 \mathrm{~m}$. apmokamų vaiko priežiūros atostogų išmokų dydis buvo sumažintas ir tèvai igijo teisę i $100 \%$ buvusio atlyginimo dydžio apmokamų atostogų iki kol vaikui sukaks vieneri metai ir i $85 \%$ - kol sukaks dveji metai. $2010 \mathrm{~m}$. ịvyko dar vienas apmokamų vaiko priežiūros sumažinimas, kuomet tèvai igijo teisę i $90 \%$ buvusio atlyginimo dydžio apmokamų atostogų iki kol vaikui sukaks vieneri metai ir ị $75 \%$ - kol sukaks dveji metai. Ženklesni pokyčiai pasijuto $2011 \mathrm{~m}$. ịsigaliojus Ligos ir motinystès socialinio draudimo įstatymo keitimo įstatymui (2011), kuomet tẻvams pasiūlytos dvi apmokamų vaiko priežiūros atostogu alternatyvos, t.y. 1) $100 \%$ buvusio atlyginimo iki vaikui sukaks vieneri metai, antraisiais metais negaunant išmokų arba 2) $70 \%$ buvusio atlyginimo dydžio išmoka pirmaisiais metais ir $40 \%$ - iki kol vaikui sukaks dveji metai.

Motinystès, tèvystès ir vaiko priežiūros atostogos, Lietuvoje kaip ir daugelyje šalių mokamos priklausomai nuo dalyvavimo darbo rinkoje ir atsižvelgiant ị turimą darbo stažą. 2011-2018 m. apmokamų vaiko priežiūros atostogų sistema detaliau pristatoma 2 lentelèje (detaliau žr. 2 lentelëje). 
2 lentelè. Motinystès, tėvystės ir vaiko priežiūros atostogų teisinis reglamentavimas Lietuvoje, 2011-2018 m.

\begin{tabular}{|c|c|c|c|}
\hline & Trukmè & Apmokèjimas/lubos & Reglamentavimas \\
\hline $\begin{array}{l}\text { Motinystės } \\
\text { atostogos }\end{array}$ & $\begin{array}{l}18 \text { savaičių ( } 126 \\
\text { kalendorinès dienos). } 70 \\
\text { kalendorinių dienų prieš } \\
\text { ir } 56 \text { dienos po kūdikio } \\
\text { gimimo. }\end{array}$ & $\begin{array}{l}100 \% \text { buvusio atlyginimo. } \\
\text { Nuo } 2017 \text { m. lubos nėra taikomos. }\end{array}$ & $\begin{array}{l}\text { Visos motinos, kurios mokèjo } \\
\text { socialinio draudimo įmokas } \\
\text { mažiausiai } 12 \text { mėn. per pastaruosius } \\
24 \text { mèn. }\end{array}$ \\
\hline $\begin{array}{l}\text { Tèvystès } \\
\text { atostogos }\end{array}$ & 28 kalendorinès dienos & $\begin{array}{l}100 \% \text { buvusio atlyginimo. } \\
\text { Taikomos } 1,617.40 \text { EUR lubos. }\end{array}$ & $\begin{array}{l}\text { Visi tėvai, kurie mokejo socialinio } \\
\text { draudimo įmokas mažiausiai } 12 \\
\text { mèn. per pastaruosius } 24 \text { mèn. }\end{array}$ \\
\hline $\begin{array}{l}\text { Vaiko } \\
\text { priežiūros } \\
\text { atostogos }\end{array}$ & $\begin{array}{l}\text { Apmokamos iki } 24 \text { mèn. } \\
\text { Neapmokamos iki } 36 \\
\text { mėn. }\end{array}$ & $\begin{array}{l}\text { Tėvai gali pasirinkti iš galimų } \\
\text { variantų: } \\
\text { 1) iki kol vaikui sukaks } 12 \text { mèn. } \\
100 \% \text { buvusių pajamų; taikomos } \\
\text { 1,617.40 EUR lubos. } \\
\text { 2) iki kol vaikui sukaks } 12 \text { mèn. } 70 \\
\text { \% buvusių pajamų; taikomos } \\
\text { 1,132.18 EUR lubos. } \\
\text { Plius iki kol vaikui sukaks } 24 \text { mèn. } \\
40 \% \text { buvusių pajamų; taikomos } \\
646.98 \text { EUR lubos. }\end{array}$ & $\begin{array}{l}\text { Visos motinos ir tèvai, kurie } \\
\text { mokèjo socialinio draudimo ịmokas } \\
\text { mažiausiai } 12 \text { mėn. per pastaruosius } \\
24 \text { mèn. }\end{array}$ \\
\hline
\end{tabular}

Šaltinis: sudaryta autoriu pagal Socialinio draudimo fondo valdybos SODRA duomenis

Nuo 2019 m. sausio 1 d. ịsigaliojęs Lietuvos Respublikos ligos ir motinystès socialinio draudimo įstatymo Nr. NR. IX-110 6, 14, 18, 21, 22, 24 straipsnių pakeitimo ịstatymas, iš esmès nepakeitè nusistovèjusios tvarkos, tačiau sumažino apmokamų vaiko priežiūros išmokų dydžius: 1) motinystės išmoka něštumo ir gimdymo atostogų laikotarpiu ir tèvystės išmoka mokama $77.58 \%$ išmokos gavèjo kompensuojamojo uždarbio dydžio ir 2) vaiko priežiūros išmokos dydis iki vaikui sueis vieni metai yra 77.58 \% išmokos gavèjo kompensuojamojo uždarbio dydžio (jeigu apdraustasis pasirenka gauti šią išmoką, kol vaikui sueis vieni metai ir jeigu apdraustasis pasirenka gauti vaiko priežiūros išmoką, kol vaikui sueis 2 metai, šios išmokos dydis iki vaikui sueis vieni metai yra $54.31 \%$, o iki vaikui sueis 2 metai - 31.03 \% išmokos gavèjo kompensuojamojo uždarbio dydžio.“

\section{Apmokamos vaiko priežiūros atostogos ir tẻvų dalyvavimas darbo rinkoje}

Mokslininkų teigimu motinystès, tėvystès ir vaiko priežiūros atostogos gali turèti (turi?) teigiamą poveikį moterų užimtumui, tačiau ilgos apmokamos vaiko priežiūros atostogos dažniausiai turi neigiamą poveikį moterų/motinų atlyginimams ir karjeros perspektyvoms (Brunning, Plantenga, 1999). Lietuva pasižymi aukštu moterų dalyvavimo darbo rinkoje lygmeniu, tačiau moterys yra mažiau palankesnèje situacijoje darbo rinkos požiūriu nei vyrai. Moterys sudaro mažumą tarp aukščiausio lygio ịmonių vadovų, nacionalinio parlamento ir vyriausybės narių ir kt. Moterų padètis darbo rinkoje gali būti apibūdinama aukštu profesinès segregacijos lygmeniu, o moterys ir vyrai užimti skirtinguose profesinès veiklos sektoriuose, kuriuos galime apibūdinti aukštu vertikalios ir horizontalios segregacijos lygmeniu. Moterys tradiciškai užimtos menkiau apmokamuose sektoriuose, t.y. švietimas, sveikatos apsauga, socialinė parama ir kt. Be to, nuo 2012 m., nuolat auga moteru ir vyrų atlyginimo skirtumai ir šis rodiklis $2017 \mathrm{~m}$. siekẻ $15.2 \%$ (palyginimui šio rodiklio vidurkis ES šalyse siekè $16.0 \%$ ). 


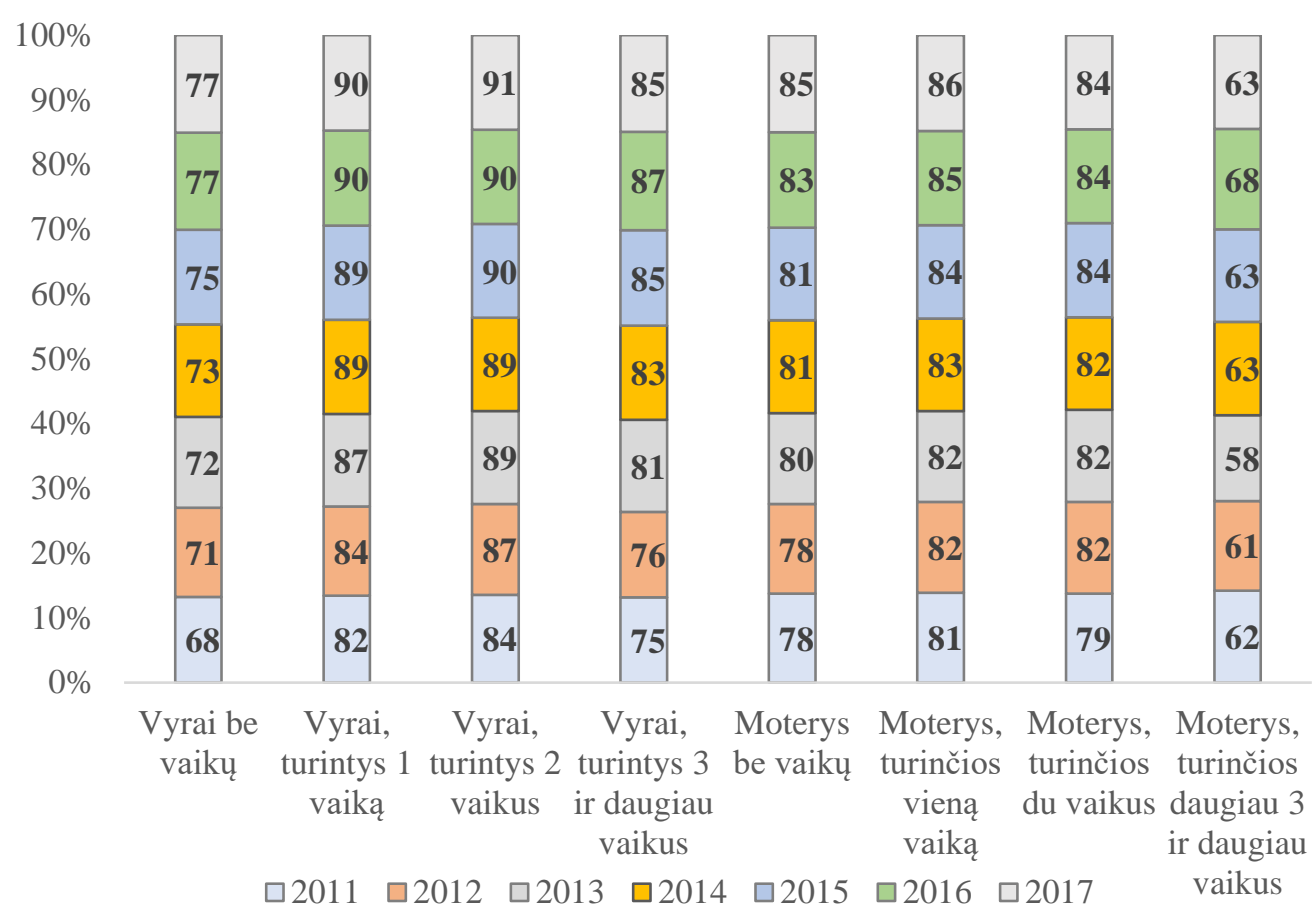

1 pav. Moterų ir vyrų užimtumo lygis pagal vaikų skaičių šeimoje Lietuvoje.

Šaltinis: EU-SILC, (lfst_hheredch)

Analizuojant tėvų ir motinų, auginančių mažamečius vaikus dalyvavimo darbo rinkoje tendencijas, pastebime, kad vaikų skaičius šeimoje tiesiogiai ịtakoja tėvų (o ypač motinų dalyvavimą darbo rinkoje). Moterų dalyvavimas darbo rinkoje mažèja su kiekvienu vaiku, o vyrų atvirkščiai, kuo daugiau vaikų turima, tuo intensyviau dalyvaujama darbo rinkoje (detaliau žr. 1 pav.). Apžvelgiant pastarųjų metų duomenis (nuo 2011), galime pažymèti, kad tendencija išlieka gana pastovi, nors moterų, turinčių mažamečius vaikus dalyvavimo darbo rinkoje lygis ir nežymiai auga.

\section{Apmokamų vaiko priežiūros atostogų pasirinkimai ir vertinimas}

Šioje dalyje išsamiai analizuojami socialinio fondo draudimo valdybos (SODRA) duomenys apie apmokamų vaiko išmokų gavèjus pagal lytị 2011-2018 m. Pažymėtina tai, nors Lietuvoje abu tèvai turi teisę pasiimti vaiko priežiūros atostogas, nepaisant to, kad dažniausiai tai daro tik motinos, pastaraisiais metais tèvų, imančių vaiko priežiūros atostogas, skaičius nuolat auga (detaliau žr. 2 pav.). Iš socialinio fondo draudimo valdybos (SODRA) pateikiamų duomenų matome, kad Lietuvoje vaiko priežiūros atostogas ima maždaug du trečdaliai moterų ir vienas trečdalis vyrų.

Kaip pasiskirsto tėvų apmokamų vaiko priežiūros atostogų pasirinkimai pagal lytị, matome iš 3 paveiksle pateikiamų duomenų. Iš administracinių duomenų matome, kad antrasis pasirinkimas gauti apmokamas vaiko priežiūros išmokas dvejus metus yra ženkliai populiaresnis nei gauti išmoką vienerius metus (detaliau žr. 3 pav.). Tokiu būdu tèvai ịgyja teisę ị $70 \%$ buvusio atlyginimo dydžio išmoką pirmaisiais metais ir 40 \% išmoką iki kol vaikui sukaks dveji metai. Nuo $2011 \mathrm{~m}$. šis skaičius išaugo daugiau nei tris kartus. Akivaizdu, kad vyrai dažniausiai renkasi išeiti apmokamų vaiko priežiūros atostogu antraisiais metais. Tas faktas, kad dauguma išmokų gavèjų renkasi antraji variantą, gauti vaiko priežiūros išmokas dvejus metus (70/40), rodo tai, kad egzistuoja trumpesnių ir lankstesnių vaiko priežiūros atostogų, ikimokyklinio ugdymo vaikams iki dvejų metų trūkumas, todèl tèvai yra linkę rinktis ilgesnes vaiko priežiūros atostogas. Vienas iš apmokamų vaiko priežiūros atostogų pasirinkimų paaiškinimų yra ženklus motinystės, tėvystės ir tėvystės atostogų išmokų dydžių skirtumas pagal lytị. Iš Valstybinio socialinio draudimo fondo valdybos (SODRA) administracinių duomenų matome, kad vidutinè tėvystės pašalpa, priklausomai nuo savivaldybės, svyruoja nuo 690 
iki 1086 eurų per mėnesį. Palyginus su motinystės išmokų dydžiais, pastarosios vidutiniškai svyruoja nuo 616 iki 880 eurų per mėnesị, o vaiko priežiūros atostogų dydžiai - nuo 352 iki 563 eurų per mėnesị, priklausomai nuo savivaldybès. Visų rūšių išmokos yra didesnès didžiųjų miestų savivaldybėse, kas iš esmès patvirtina regioninius darbo užmokesčio skirtumus.

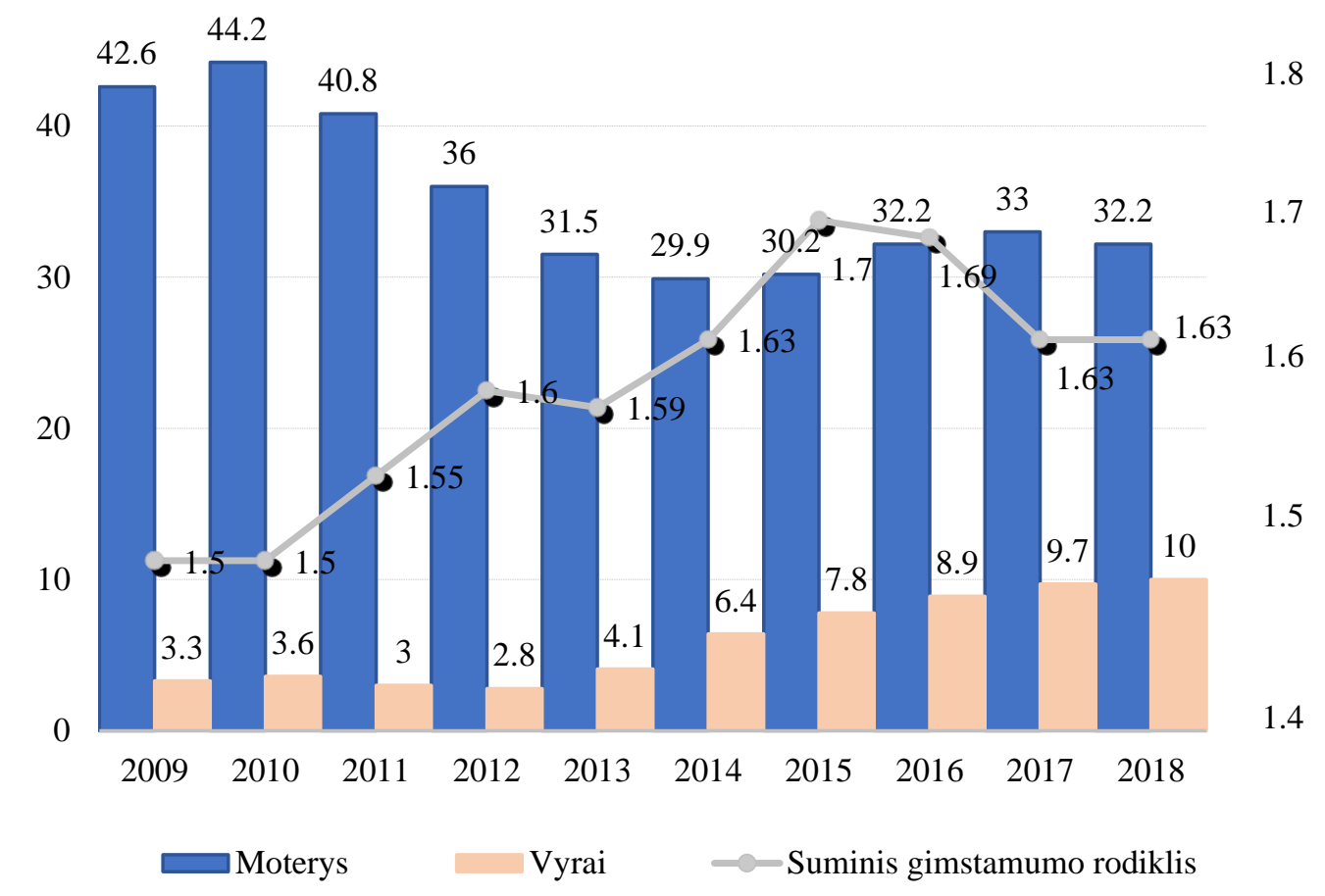

2 pav. Vaiko priežiūros išmokų gavèjų skaičius pagal lytị (\%) bei suminis gimstamumo rodiklis, 2009 - 2018.

Šaltinis: Lietuvos statistikos departamentas ir Eurostat (tps00199)

Apmokamų vaiko priežiūros atostogų sistema Lietuvoje veikia tik kaip buvusio/prarasto uždarbio kompensavimo mechanizmas ir akivaizdžiai yra pagrịsta finansinès naudos motyvais, bet iš esmès menkai prisideda prie palankesnių prielaidų sukūrimo derinant apmokamą darbą ir vaikų priežiūrą. Mūsų atlikto mokslinio tyrimo radiniai yra labai panašūs su $2014 \mathrm{~m}$. atlikto T. Šarlausko ir A.Telešienès (Šarlauskas, Telešienè, 2014) moksliniu tyrimo rezultatais, kur autoriai teigia, kad „Lietuvoje populiaresnis dvejų metų išmokos laikotarpis ir santykinè šio pasirinkimo dalis tik didèja Taip pat galima patvirtinti išvadą, kad santykinai labiausiai didèja vyrų, pasirinkusių gauti išmoką iki dvejų metų, dalis. Vertinant apmokamų vaiko priežiūros atostogų sistemą, galima konstatuoti, kad pastaroji sistema neskatina lyčių lygybės ar didesnio vyrų įsitraukimo ị vaikų priežiūrą. Kaip pažymi Šarlauskas ir Telešienè (2014), ,istatyminių normų intencijos atrodo teigiamos, nes siūloma nuo antrujų vaiko metų atkurti darbinius saitus ir užsitikrinti darbines pajamas", tačiau realybèje moterys ženkliai dažniau priima atsakomybę už vaikų priežiūrą. Šiame kontekste paminètinas ir dar vienas aspektas, kad Lietuva iki šiol nèra pasiekusi vieno iš esminių Barselonos strategijos tikslo, t.y., kad ne mažiau nei 33 \% vaikų iki trejų metų lankytų ikimokyklines vaikų ugdymo ịstaigas, todèl didelè dalis mažamečių vaikų nuo vienerių iki dvejų metų amžiaus yra prižiūrimi namuose. 


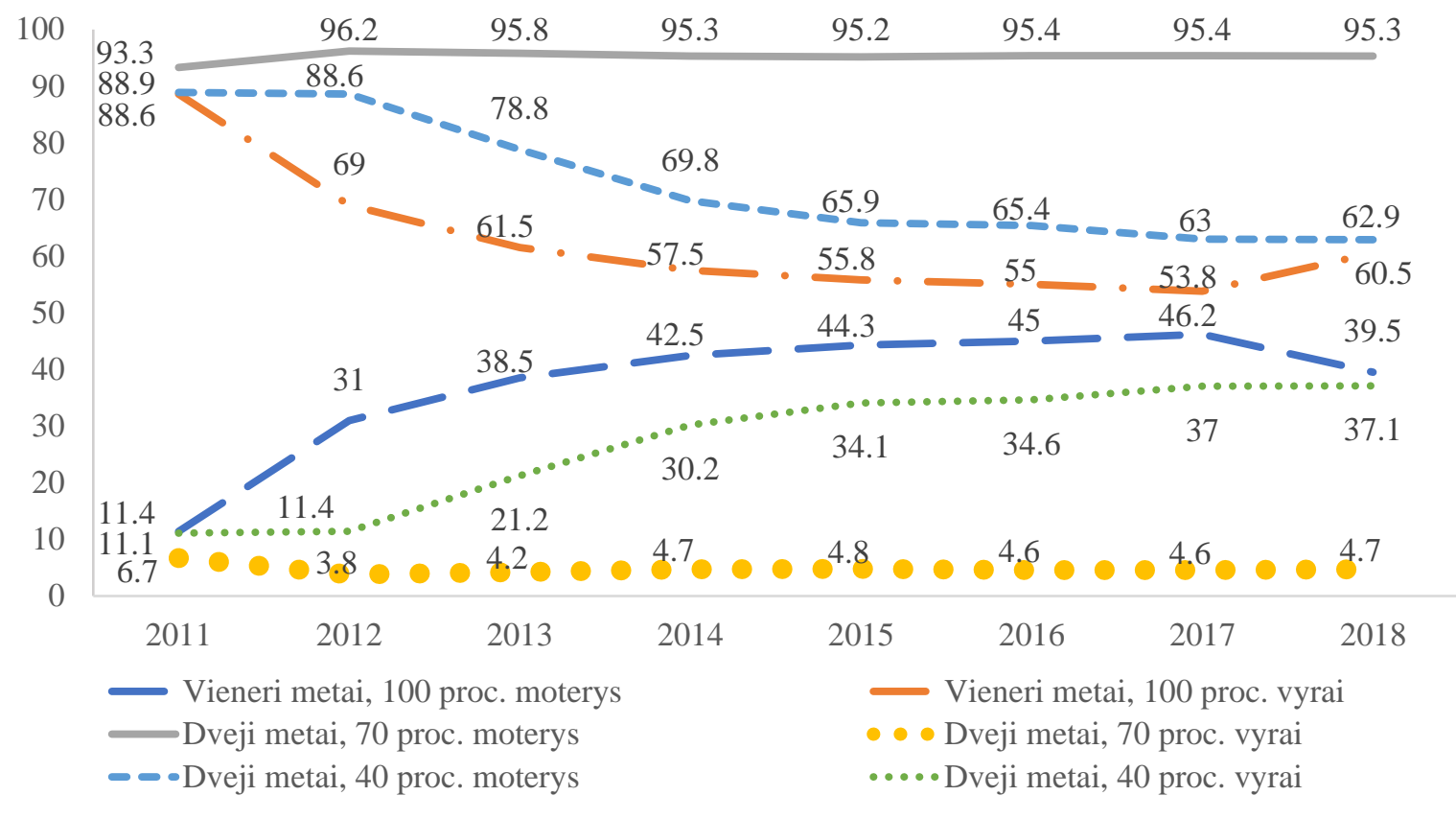

3 pav. Vaiko priežiūros išmokų gavėjų pasirinkimai pagal lytị 2011-2018 m.

Šaltinis: Socialinio fondo draudimo valdyba (SODRA) duomenys: open.sodra.lt file pasalpos.xlsx

\section{Išvados ir rekomendacijos}

1. Atlikus mokslinès literatūros, strateginių bei teisinių dokumentų, antrinių duomenų analizę, galima padaryti išvadą, kad Lietuvoje egzistuojanti apmokamų vaiko priežiūros atostogų sistema iš esmès orientuota tik i prarastų pajamų kompensavimą tẻvams, tačiau nesudaro lygiu galimybių tolygiam abiejų tėvų ịsitraukimui ị vaikų priežiūrą bei dalyvavimą darbo rinkoje. Tą faktą patvirtina ir statistiniai duomenys. Du kartus daugiau moterų nei vyrų naudojasi apmokamomis vaiko priežiūros atostogomis, o moterų, turinčių mažamečių vaikų dalyvavimo darbo rinkoje rodikliai ženkliai mažèja. Motinų ir tėvų apsisprendimą išeiti vaiko priežiūros atostogų pirmiausiai nulemia finansiniai motyvai, sąlygoti mažesnių išmokų dydžių motinoms bei kitų paramos formų šeimai stoka. Panašią išvadą formuluoja ir $2014 \mathrm{~m}$. atlikto mokslinio autoriai (Šarlauskas, Telešienè, 2014), teigdami, kad ,Socialinio fondo valdybos (SODRA) ekspertų interviu analizės rezultatai rodo, jog Lietuvoje populiaresnè dvejų metų 70 ir $40 \%$ pašalpų sistema visgi neskatina vyrų prisiimti vaikų priežiūros įsipareigojimų".

2. Už apmokamų vaiko priežiūros atostogų sistemą atsakingoms institucijoms (Socialinès apsaugos ir darbo ministerijai, Socialinio fondo draudimo valdybai ir t.t.), rekomenduojama Lietuvoje peržiūrèti apmokamų vaiko priežiūros atostogų modelị, kuris iš esmès sudarytų palankesnes prielaidas (darbas ne visą darbo dieną, tolygesnis apmokamų vaiko priežiūros atostogų pasidalinimas tarp tèvų (ịvedant atostogų laikotarpius, kurie skirti tik vyrams arba tik moterims ir t.t.) abiem tėvams dalyvauti tiek darbo rinkoje, tiek vaikų priežiūroje.

\section{Literatūra}

1. Almqvist, A. L., Duvander, A. Z. (2014). Changes in gender equality? Swedish fathers' parental leave, division of childcare and housework Journal of Family Studies, 20:1, 19-27, DOI: 10.5172/jfs.2014.20.1.19

2. Braziene, R. (2019). Lithuania country note, in Koslowski, A., Blum, S., Dobrotić, I., Macht, A. and Moss, P. (eds.) International Review of Leave Policies and Research 2019. Available at: http://www.leavenetwork.org/lp_and_r_reports/ 
3. Braziene, R. (2018). 'Lithuania country note', in: P. Moss (ed.) International Review of Leave Policies and Research 2017. Available at: http://www.leavenetwork.org/lp_and_r_reports/

4. Braziene, R. (2017). 'Lithuania country note', in: P. Moss (ed.) International Review of Leave Policies and Research 2016. Available at: http://www.leavenetwork.org/lp_and_r_reports/

5. Braziene, R., Purvaneckiene, G. (2016). 'Lithuania country note', in: P. Moss (ed.) International Review of Leave Policies and Research 2015. Available at: http://www.leavenetwork.org/lp_and_r_reports/

6. Braziene, R., Daukantienè, N. (2010). Accessibility to childcare facilities, gender, and reconciliation of work and family life in Lithuania // Social Research = Socialiniai tyrimai: mokslo darbai / Šiaulių universitetas. Šiauliai: Šiaulių universiteto leidykla. ISSN 1392-3110, nr. 1(18), p. 53-62. [IndexCopernicus; SocINDEX with Full Text; CEEOL; Current Abstracts; TOC Premier]

7. Castles, F. C., (2003). The world turned upside down: below replacement fertility, changeing preferences and family-friendly public policy in 21 OECD countries. Journal of European Social Policy, 13 (3).

8. Duvander, A. Z., Ellingsæter, A. L., (2016). Cash for childcare schemes in the Nordic welfare states: diverse paths, diverse outcomes. European Societies, 18:1, 70-90, DOI: 10.1080/14616696.2015.1124903

9. Eydala, G. B., Ingólfur V. G., Rostgaardc t., Brandthd B., Duvander A. Z., Lammi-Taskula, J. (2015). Trends in parental leave in the Nordic countries: Has the forward march of gender equality halted? Community, Work \& Family, 18:2, 167-181, DOI: 10.1080/13668803.2014.1002754 http://dx.doi.org/10.1080/13668803.2014.1002754

10. Evertsson M., Duvander A. Z., (2011). Parental Leave-Possibility or Trap? Does Family Leave Length Effect Swedish Women's Labour Market Opportunities? DOI:10.1093/esr/jcq018, available online at www.esr.oxfordjournals.org 435-450

11. Esping - Andersen, G. (1990). The Three Worlds of Welfare Capitalism. Polity Press. Cambridge.

12. Espring - Andersen, G. (1996). After the Golden Age? Welfare State Dilemmas in a Global Economy. In Welfare States in Transition: National Adaptations in Global Economies. London: Sage publications.

13. Esping - Andersen, G. (1999). Social Foundations of Post-industrial Economies. Oxford University Press. Oxford, New York.

14. Ferrarini T., Duvander A.Z. (2009). Earner-Carer Model at the Crossroads Reforms and Outcomes of Sweden's Family Policy in Comparative Perspective RC19 conference in Montreal August 20-22.

15. Gender Equality Index 2019. family-friendly Balance. Europos lyčių lygybės institutas. Prieiga per internetą: https:/eige.europa.eu/publications/ gender-equality-index-2019-work-lifebalance.

16. Hoyman, M., Duer, H. (2004). A Typology of Workplace Policies: Worker Friendly vs. Family Friendly? Public Personnel Administration. Vol. 24.

17. Jančaitytè R. (2006). Palankios šeimai politikos igyvendinimas Lietuvoje: problemos ir galimybès. Socialinis darbas. Nr. 5 (1).

18. Lietuvos Respublikos ligos ir motinystės socialinio draudimo įstatymas. Valstybės žinios, 2000, Nr. 111-3574.

19. Lietuvos respublikos ligos ir motinystès socialinio draudimo įstatymo Nr. NR. IX-110 6, 14, 18, 21, 22, 24 straipsnių pakeitimo istatymas. https://e-seimas.lrs.lt/portal/legalAct/lt/ TAD/7f76aa757b7a11e89188e16a6495e98c [2019-05-02].

20. Mabala, S.P. (2019). „Incomplete revolution: role of welfare states in women's revolution “

21. Neyer, G. (2003). Family Policies and Low Fertility in Western Europe. MPIDR Working Paper WP 2003-021. Prieiga per internetą http://www.demogr.mpg.de. 
22. O'Brien M., (2017). Comparative Perspectives on Work-Life Balance and Gender Equality Fathers on Leave Alone ISSN 2211-7776 ISSN 2211-7784 (electronic) Life Course Research and Social Policies ISBN 978-3-319-42968-7 DOI 10.1007/978-3-319-42970-0

23. Reingardienè J., Tereškinas A. (2006). Darbo ir šeimos gyvenimo suderinimas Lietuvoje bei lyčių lygybė: iššūkiai ir galimybès. Sudarytoja: Reingardienė J. (Ne)apmokamas darbas: šeimai palanki darbo aplinka ir lyčių lygybė Europoje. Vytauto Didžiojo universitetas, Lygių galimybių plètros centras. Vilnius.

24. Stankūnienė V. ir kt. (2001). Paramos šeimai politika: samprata ir patyrimas. Vilnius: Lietuvos filosofijos ir sociologijos institutas.

25. Stankūnienė V. ir kt. (2003). Šeimos revoliucija? Iššūkiai šeimos politikai. Vilnius: Socialinių tyrimų institutas.

26. Šarlauskas T., Telešienè A. (2014). Valstybinio socialinio draudimo motinystės (tèvystès) išmokų reglamentavimas: pašalpų gavèjų struktūra ir pasirinkimai. Viešoji politika ir administravimas. Kauno technologijos universitetas, Mykolo Romerio universitetas. Kaunas: Technologija. ISSN 1648-2603. Vol. 13, No 1, p. 95-108. [IndexCopernicus; Academic Search Complete; Central \& Eastern European Academic Source;].

27. Valarino I., Duvander A. Z., Haas L., Neyer G. (2015). Leave Policy Preferences in a Comparative Perspective https://www.researchgate.net /publication/283046711

28. Valarino I., Duvander A. Z., Haas L., Neyer G., (2018). Exploring Leave Policy Preferences: A Comparison of Austria, Sweden, Switzerland, and the United States. Social Politics Volume 25 Number 1

29. Valstybinė šeimos politikos koncepcija. Valstybės žinios, 2008, Nr. 69-2624.

30. Valstybinio socialinio draudimo fondo valdybos (,Sodros“") statistinių duomenų portalas. http://atvira.sodra.lt [2019-06-01].

31. Vyšniauskienė, S., Brazienė, R. (2017). Palankios šeimai politikos vertinimas Lietuvoje. Viešoji politika ir administravimas. Kauno technologijos universitetas, Mykolo Romerio universitetas. Kaunas: Technologija. ISSN 1648-2603. nr. 17, p. 455-467. [IndexCopernicus; Academic Search Complete; Central \& Eastern European Academic Source;].

Rūta Brazienè, Sonata Vyšniauskienè

\section{Evaluation of Paid Leave Policies in Lithuania}

\section{Abstract}

The article discusses the paid parental leave policy. It presents the legal regulation, the family support system in Lithuania and debates the assessment of the paid parental leave system from a gender equality perspective. An overview of the latest and most relevant scientific literature on family-friendly policies and paid parental leave is presented. Based on the Labour Force Survey (Eurostat LFS), Statistics Lithuania and the Social Fund Board (SODRA) data the main trends of parents with children in the labour market, and choices and estimates for paid maternity and paternity leave is analysed. The results of the research revealed that the system of paid parental leave in Lithuania is mainly aimed at compensating parents lost income, but does not provide equal opportunities for both parents to be equally involved in childcare and participate in labour market. This fact is also confirmed by statistics showing that twice as many women than men take paid parental leave, while the participation rate of women with young children is significantly decreasing. Mothers' and fathers' decisions to take parental leave are primarily driven by financial considerations resulting from lower benefits for mothers. 
Rüta Braziené, Vilniaus universiteto, Filosofijos fakulteto docentė, socialinių mokslų daktarè. email: ruta.braziene@fsf.vu.lt

Sonata Vyšniauskiené, Lietuvos socialinių tyrimų centro, Sociologijos instituto jaunesnioji mokslo darbuotoja, doktorantè.

email: sonata.vysniauskiene@1stc.lt

Rüta Braziene, Doctor of Social Sciences, Associate Professor at the Faculty of Philosophy, Vilnius University

email: ruta.braziene@fsf.vu.lt

Sonata Vyšniauskienè, PhD Student, Junior Researcher at the Institute of Sociology, Lithuanian Social Research Centre

email: sonata.vysniauskiene@1stc.lt 